\title{
Students' Perceptions of FlipPed APPROACH in EFL Classroom: A SURVEY RESEARCH
}

\author{
Eka Duriyatul Muhlisoh ${ }^{1)}$, Asih Santihastuti ${ }^{2)}$, Eka Wahjuningsih $^{3)}$ \\ ${ }^{1)}$ Universitas Jember, Jember, Indonesia \\ E-mail: eka.dm97@gmail.com \\ ${ }^{2)}$ Universitas Jember, Jember, Indonesia \\ E-mail: santihastuti@gmail.com \\ ${ }^{3)}$ Universitas Jember, Jember, Indonesia \\ E-mail: merrynining@gmail.com
}

\begin{abstract}
This research investigated the implementation of Flipped Approach in EFL classroom with the implementation of the E-learning platform. The participants were 42 sophomore English majors of Advanced Paragraph Writing class at Jember University. A within-subjects research design exposed all participants to have Writing Class by flipped learning and to use the E-learning platform. A one-shot survey design was used in this research by distributing two questionnaires "Perception of Flipped Learning Experience" and "Technology Acceptance Model" and doing the inclass observations as "Flipped Note" to collect the data. Data were analyzed quantitatively through SPSS 16.0 by applying the formula of Descriptive Statistics. The results of this research revealed that the implementation of the flipped approach in the classroom: (1) motivated the students in learning the materials, (2) enhanced the students' knowledge, (3) and engaged them more in the learning tasks. They explained that the flipped approach gave them a new experience in language learning processes, in which they learned the materials before coming to the classroom so that they could criticize the materials. This way of learning aligns with the idea of student-centred learning. It is notable, however, that the students who did not learn the materials yet, could not criticize the materials and could not reach better outcomes in flipped classroom Moreover, the use of E-learning in the flipped classroom gave the students beneficial outcomes in the learning processes. Students revealed on the Technology Acceptance Model questionnaire that E-learning facilitates them properly, and they wanted to look forward to having E-learning in the future learning processes. Despite this finding, there remain limitation on the "server down" issue which needs to be straightened for more accessible Elearning among users.
\end{abstract}

Keywords: Flipped Approach; E-Learning Platform; Academic Writing Class; EFL Learners

\section{INTRODUCTION}

For generations, teachers have taught their students through conventional teaching which basically takes places in the classroom. (Afrilyasanti, Cahyono, \& Astuti, 2016). This practice, however, has several drawbacks, such as students in conventional classroom often become confused and frustrated, which can lead to misconceptions (Kirschner, Sweller, \& Clark, 2006). It happens because the information may come too slowly or cover the information that students already knew (Souza \& Rodrigues, 2015). Besides, students are not directed to actively engage in the learning process, instead, they are forced to listen to teachers' explanations, and record the information by taking some notes which resulting passive classroom instruction (Khalaf \& Zin, 2018). Teachers subsequently give homework to substantiate students' understanding, in doing their homework, students might not have any assistance to help them when they feel confused about the vague concepts (Afrilyasanti, Cahyono, \& Astuti, 2016). In fact, if students want to clear their confusion, they still have to wait until the following meeting to have their teacher's assistance (Bergmann \& Sams, 2012:14). As a result, conventional teaching is considered an ineffective, inefficient and irrelevant pedagogical approach in the classroom (Souza \& Rodrigues, 2015). 
As the enhancement of technology develops rapidly, the flipped classroom is introduced. This technologically based teaching paradigm reverses the teaching-learning practice in a conventional class by making the students acquire the knowledge outside the classroom. In the flipped classroom, students acquire their knowledge at home by watching videos and/or reading passages as their homework. Thereafter, school time will be used to apply their knowledge in the form of problem-solving and practical work (Hsieh, Wu, \& Marek, 2017). In this case, students who experienced misconceptions will get the most help because they do not need to attend the lecture to listen to the teacher presents the information, instead, they take on more tutorial roles (Bergmann \& Sams, 2012:14). Furthermore, after the classroom session, students still have chances to re-play videos or re-read passages that have been shared by teachers in any online learning platform, such as Elearning websites to have a deeper understanding (Roth \& Suppasetseree, 2016).

The implementation of the flipped classroom has been investigated by some researchers in different classes through different online learning platforms with different purposes, such as Facebook in General English Class (Quyen, 2017), Elearning in Computer Class (Yilmaz, 2017), Moodle in General English classes (Evseeva \& Solozhenko, 2015; Nouri, 2016), Line in Oral Training Classes (Hsieh, Wu, \& Marek, 2017; Hsieh, Huang, \& Wu, 2017), and Websites in Writing and Computer Classes (Afrilyasanti, Cahyono, \& Astuti, 2016; Sohrabi \& Iraj, 2016; Sojayapan \& Khlaisang, 2018; Fauzan \& Ngabut, 2018). In general, the implementation of the online learning platform in the Flipped Classroom resulted in positive results. Besides, the previous study was conducted in the Writing Class by implementing the Websites platform, which was not specifically explained by the researcher. Meanwhile, in the present study, the research was conducted in the Writing Class by implementing an E-learning platform. Students in the Writing Class might need more time to practice their writing skill outside the classroom and use the offline class for the consultation. Having the concept of Flipped Approach, the researcher expects that students can have more time to consult their writing inside the classroom. Considering the information above, the researcher would like to investigate the utilization of E-learning in Writing Class by using Flipped Instruction. Moreover, the present study was done in Advanced Writing Class, in the English Department at Jember University, with some considerations, first, Jember University releases a new version of the E-learning platform that assesses the students work. Second, the finding of the study is expected to contribute knowledge about how well Elearning plays its role in the flipped classroom, and how well E-learning plays its role as the official online platform of Jember University. Considering the information above, this research involves two research questions:

1. How do the students perceive the flipped class learning experience?

2. How do the students perceive the platform selected for the flipped learning treatment?

\section{Methodology}

This research applied survey research as the objective is to investigate the students' perceptions of the flipped approach on E-learning in Writing Class. The design of this research is One-Shot Survey Design because a one-shot survey was employed to determine the current perception of one group at one point in one time (Lodico, Spaulding, \& Voegtle, 2010:199).

20-item-questionnaires adapted from Hsieh, Wu, \& Marek (2017) was distributed to investigate students' perceptions on two questionnaires, which are Perception of Flipped Learning Experience with four constructs (Motivation, Effectiveness, Engagement, and Overall Satisfaction), and Technology Acceptance Model with three constructs (Perceived Ease of Use, Perceived Usefulness, and Attitude about Use). Additionally, the questionnaires were administered in the Likert Scale Model. Ary et al. (2010:209) explained a Likert Scale is used to measure attitudes. It consists of the number of statements that asking the respondent to indicate whether they strongly disagree $=1$, disagree $=2$, agree $=3$, or strongly agree $=4$. As the researcher of the present study did not conduct an interview, therefore each statement on the questionnaires has blank space which is provided for students to write their opinion or reason related to their personal experiences on the Flipped Classroom, and classroom observation (flipped note) was done by the researcher to support the results of students' perception. Moreover, the questionnaires were written in English and Indonesian to avoid misunderstanding.

Also, the participants were the whole population of paragraph writing $\mathrm{C}$ class of English department at Jember University, consisting of 42 students, who had no experience in joining flipped class before. The writing class implemented flipped class because the class needs extra time to work on their composition as well as to get both consultation and feedback from teachers or their peers on their writings.

Furthermore, the result of two questionnaires provides numerical data which were analyzed quantitatively through SPSS 16.0 by applying the formula of Descriptive Statistics. The researcher counted the mean score of each item on the questionnaires and the mean score of each construct on the questionnaires. The mean score is the result of the division of the Total Number of Items to the Number of Responses. If mean score $>$ (minimum + maximum) $: 2=$ Upperintermediate (positive) and if mean score < (minimum + maximum) : 2 = Lower intermediate (negative) (Hsieh, Wu, \& Marek, 2017).

\section{RESULTS AND DISCUSSION}

The analysis of the questionnaires revealed that in general, the theory-based flipped classroom treatment motivated the students in learning the materials, enhanced the students' knowledge, improved their writing ability, and engaged them more in the learning tasks. The results of the questionnaires will be explained more in the following paragraphs and are organized by the research questions. 


\section{A. Students perception of the flipped class learning experience}

The first questionnaire was used to evaluate the students' overall perceptions of the implementation of the flipped approach in the Classroom. The results as shown in Table I revealed that the participants' responses to four constructs were categorized as upper-intermediate (Hsieh, Wu, \& Marek, 2017). Based on the results, it can be revealed that the implementation of the flipped approach in the classroom (1) motivated the participants to learn the materials and to improve their writing ability, (2) enhanced the participants' knowledge and writing ability, and (3) engaged the participants in the learning processes and tasks.

TABLE I

DESCRIPTIVE STATISTICS OF THE PERCEPTION OF THE FLIPPED LEARNING EXPERIENCE

\begin{tabular}{lllll}
\hline \multicolumn{1}{c}{ Constructs } & $\begin{array}{c}\text { N of } \\
\text { items }\end{array}$ & Mean & Min & Max \\
\hline Motivation & 4 & 3.39 & 1 & 4 \\
Effectiveness & 3 & 3.19 & 1 & 4 \\
Engagement & 3 & 3.34 & 1 & 4 \\
Overall satisfaction & 1 & 3.38 & 1 & 4 \\
\hline
\end{tabular}

Note: $N$ of participants $=42 ;$ Minimum Score $=$ the lowest score of students' perception result on the questionnaires (Appendix 3, p: 4345); Maximum Score= the lowest score of students' perception result on the questionnaires (Appendix 3, p: 43-45).

Hsieh, Wu, \& Marek (2017) indicated that the participants can evaluate their flipped learning experiences via four constructs: motivation, effectiveness, engagement, and overall satisfaction. The motivation construct was related to students' self-motivation in following the flipped learning processes. By applying the concept of the flipped approach, students can understand and comprehend the materials to become their background knowledge before attending the class (Zainuddin, 2018). Awidi \& Paynter (2018) added that students are likely to feel more motivated when they give allow sharing information dealing with their background knowledge about the related materials. Considering the results of the flipped note, it was found that the lecturer always gave questions related to the materials the students have learned. It is to promote the students' knowledge construction during the inclass flipped activities (Kong \& Song, 2015). Some students showed their motivation by actively answering the lecturer's questions. This fact is under the statement of Giesbers et al. (2013) who claimed that students who are motivated will likely engage themselves more confidently during in-class activities in the flipped classroom. It was found, however, that the idea of developing the students' background knowledge in pre-class activity did not help motivate the students in flipped learning. Based on the research observation there some students being passive during the instruction. The researcher noticed that some students played with their cellphone instead of answering the lecturer's questions. Later, it was revealed, based on their answer on the questionnaire that they did not learn the materials yet and/or they were shy to speak up. Zainuddin (2018) found a significant finding, the pre-class activity in the flipped classroom was not the main factor of motivating students' learning in the flipped classroom. Instead, it was the gamified activity. Zainuddin (2018) followed the recommendation from Araujo, Otten, \& Birisci (2017) that the implementation of a new strategy in flipped classrooms is much needed in increasing students' content mastery before class. Furthermore, the results of the questionnaires showed that for "motivation construct", the students who responded "Agree" $(M=5)$ and "Strongly Agree" $(M=27)$ were in a great number, with a mean score of 3.39. They claimed that the flipped approach has an effective and efficient way to learn, Chilingaryan \& Zvereva (2017) claimed that the flipped approach produced more efficient use of time. It was found from the students' answers in the questionnaires that in Flipped Classroom they had a chance to learn the materials in their way, had more time to learn the materials, experienced a new sense of learning, and came to the classroom with their understanding to the materials. This condition is described as a potential benefit of flipped learning (Roach, 2014). Thus, the flipped approach is an approach that could increase the students' motivation in learning the materials (Akcayir \& Akcayir, 2018; Chilingaryan \& Zvereva, 2017).

Moreover, Effectiveness Construct on the questionnaire deals with the idea of how effective the flipped classroom was for the students. The descriptive statistic of the "effectiveness construct" resulted in 3.19 as the mean score. Most of the students responded "Agree" and "Strongly Agree". They particularly explained that the flipped approach was effective for them to develop their understanding of the materials and enhance their writing skill. It was because they had more time to practice their skill outside the classroom, as the face-to-face interactions in classroom meeting were used to have a deeper understanding and/or perceiving immediate feedback from the lecturer. Face-to-face interactions in the flipped classrooms between the lecturer and the students with immediate feedback are important to foster the students' learning $(\mathrm{Ng}$, 2018). Also, this learning activity can lead to the development of intense interaction between the lecturer and the students (Wang, 2017; Lin, 2018). Moreover, this finding has a similar finding with the result of the research conducted by Afrilyasanti, Cahyono, and Astuti (2016) who investigated the effect of the flipped classroom on EFL students' writing ability. They compared two different classes, it was flipped class and conventional class and found out that students with flipped instruction treatment had achieved better writing ability than those with conventional treatment. Therefore, it can be said that the flipped approach promotes the students' better-writing ability. It is notable, however, although most of the students responded "Agree" and "Strongly Agree", there were about 6 students who responded, "Strongly Disagree". They thought that the flipped classroom was time-consuming. It was because they have to work harder by spending more effort and time to learn the materials outside the classroom. Also, it aligns with the result of the research that was done by Dehghanzadeh, \& Jafaraghaie (2018). The participants of the research revealed the disadvantage of the flipped classroom that pre-classroom activities were time-consuming. For example, the students had to download and to learn the materials before the classroom (Gilboy, Heinerichs, \& 
Pazzaglia, 2014). Thus, although flipped classroom was effective for developing the students' learning outcomes, the time-consuming issue is seen as the disadvantage of flipped class based on the students' perceptions.

Furthermore, the "engagement construct", deals with the students' engagement in the flipped classroom. They revealed that they have spent more time and effort than usual because they are forced to learn the instructional materials before coming to the classroom and applying it during the in-class activities (Alten et al, 2019). This effort leads to the real learning process, which, happens when the students are directly engaged with the materials via active student-centred learning (Hsieh, Wu, \& Marek, 2017). In this way, the students achieve a deeper understanding of the materials (Chi $\&$ Wylie, 2014). Based on the flipped note, during the in-class activity students can actively involve the learning process by answering the lecturer's questions, which means the students engaged themselves more during the flipped learning. Also, the flipped approach is one of the most effective studentcentred instructional models (Hao, 2016). According to Chilingaryan \& Zvereva (2017), the flipped classroom is where the teacher-centred is transformed into student-centred. In which, based on the flipped note, it was found, the students were asked to read passages themselves, instead, the teacher explained the materials in detail. Moreover, the transformation of teacher-centred into student-centred is immensely influenced by learner autonomy (Boyadzhieva, 2016). Additionally, Najeeb (2013) mentioned three basic pedagogical principles of learner autonomy in language learning, there are: "learner's involvement (engaging learners to share responsibility for the learning process), learner's reflection (helping learners to think critically when they plan, monitor and evaluate their learning) and appropriate use of target language (using the target language as the principal medium of language learning)". Considering those three basic principles, based on the flipped note, it was found out that only some of the students fulfilled the basic principles of learner autonomy. The other students did not seem to accustom to student-centred learning, where they have a responsibility in learning the materials by themselves, but depended on the lecturer more. In other words, the students did not engage themselves more in the flipped learning processes. Similarly, the participants in other studies (Duong \& Seepho, 2014; Haddad, 2016; Yildirim, 2012) believed that teachers had more experiences and knowledge of assessment than students. Therefore, they depended more on teachers' direction and evaluation. It is because "autonomy is a process and is not something that will happen overnight" (Lazar, 2013). It takes time, and replaces familiar teaching methods with totally new ones is not an easy task (Erturk, 2016; Tran \& Duong, 2018; Yagcioglu, 2018). Therefore, the finding over the lack of students' engagement in this research was not surprising. It is also notable that students generally had a positive perception of the "engagement construct" if it is referred to as the result of the questionnaire where the mean score was 3.34, which means positive (Hsieh, Wu, \& Marek, 2017). They revealed that they have experienced pleasure in the flipped classroom in which they perceived immediate feedback from the lecturer, in this case on the results of their writing. It is reasonable since the flipped learning increased the contact time between the students and the lecturer (Chilingaryan \& Zvereva, 2017). Thus, in general, it can be said that the students were satisfied with the concept of flipped approach, although some did not follow the instructions well, such as they did not download the materials given, they did not read the materials, they did not share their problems, and they did not actively engage in the learning processes.

\section{B. Students Perception of the Platform Selected for the Flipped Learning Treatment}

The questionnaire on Technology Acceptance Model was used to answer research question number two and to measure students' overall perceptions of the use of E-learning in the classroom. The results were categorized as upper-intermediate, which means positive (Hsieh, Wu \& Marek, 2017). Table II showed the three constructs: perceived ease of use $(M=3.34)$, perceived usefulness $(M=3.20)$, and attitude about the use $(\mathrm{M}=3.41)$.

TABLE II

DESCRIPTIVE STATISTICS OF THE TECHNOLOGY ACCEPTANCE MODEL

\begin{tabular}{lcccc}
\hline \multicolumn{1}{c}{ Constructs } & $\begin{array}{c}\boldsymbol{N} \text { of } \\
\text { items }\end{array}$ & Mean & Min & Max \\
\hline Perceived Ease of Use & 2 & 3.34 & 2 & 4 \\
Perceived Usefulness & 3 & 3.21 & 1 & 4 \\
Attitude About Use & 4 & 3.41 & 2 & 4 \\
\hline
\end{tabular}

Note: $N$ of participants $=42$; Minimum Score $=$ the lowest score of students' perception result on the questionnaires (Appendix 3, p: 4345); Maximum Score = the lowest score of students' perception result on the questionnaires (Appendix 3, p: 43-45).

According to Chen et al. (2014), it is possible to use digital technology in the form of an online learning platform in a flipped classroom to engage the students in the home-based study before the school-based study. It is a known fact that the students in the flipped classrooms get through the home-based study to gain their knowledge before the classroom (Sohrabi \& Iraj, 2016). In this case, E-learning is the only platform suggested at Jember University and it is not popular yet among the students. Having this in reality, the result of the students' perception of the questionnaire was surprising. They revealed that E-learning is an effective, efficient, and simple learning platform. It also gave beneficial outcomes to the students. Besides, it was also mentioned that E-learning facilitated them to download the materials given by the lecturer, to submit their work as well, and the most significant thing is that they possibly can fix their work outside the classroom; it was because everything was done digitally. Digital media used in the classroom can empower both lecturers and students in transforming teaching and learning processes from teacher-centred learning to student-centred learning (Trucano, 2005). A similar finding was found in other studies (Quyen, 2017; Yilmaz, 2017) that the use of digital media in the flipped classroom resulted in positive perceptions from students, and gave beneficial outcomes to them. Moreover, digital media help the students to search for 
more sources (Soliman, 2016). Some students revealed on the questionnaire that when the materials shared were not understandable enough for them they could search for different sources to support their understanding of the materials. For this finding, it was surprising indeed that the students feel very positively about the use of an online platform although they are not too familiar with the use. Thus, generally, E-learning gives beneficial outcomes for students in the learning processes and they revealed that they would like to look forward to the use of E-learning in future learning. Despite this finding, there remain limitations on the "server down" issue which needs to be straightened for more accessible E-learning among users.

\section{CONCLUSION}

The results of this research revealed that the implementation of the flipped approach in the classroom: (1) motivated the students in learning the materials, (2) enhanced the students' knowledge, (3) and engaged them more in the learning tasks. They explained that the flipped approach gave them a new experience in language learning processes, in which they learned the materials before coming to the classroom so that they could criticize the materials. This way of learning aligns with the idea of student-centred learning. It is notable, however, that the students who did not learn the materials yet, could not criticize the materials and could not reach better outcomes in flipped classroom Moreover, the use of E-learning in the flipped classroom gave the students beneficial outcomes in the learning processes. Students revealed on the Technology Acceptance Model questionnaire that E-learning facilitates them properly, and they wanted to look forward to having E-learning in the future learning processes. Despite this finding, there remain limitation on the "server down" issue which needs to be straightened for more accessible E-learning among users.

Furthermore, based on the limitation of this research that this research was done in five classroom meetings, the researcher would like to suggest future practices. The implementation of the flipped approach in the language classroom must be at least in the whole semester so that the students will be more aware of the flipped approach concepts. It is also expected that this practice could facilitate the students' "Disagreement" and "Strongly Disagreement" responses to the questionnaires. This means that more students can have more beneficial outcomes towards the implementation of Flipped Approach in the classroom.

\section{REFERENCES}

Afrilyasanti, R., Cahyono, B. Y., \& Astuti, B. U. (2016). Effect of Flipped Classroom Model on Indonesian EFL Students' Writing Ability Across and Individual Differences in Learning. International Journal of English Language and Linguistics Research, 65-81.

Akcayir, G., \& Akcayir, M. (2018). The flipped classroom: A review of its advantages and challenges. Computers \& Education.
Alten, D. D., Phielix, C., Janssen, J., \& Kester, L. (2019). Effects of Flipping the Classroom on Learning Outcomes and Satisfaction: a Meta-Analysis. Educational Research Review, 1-18.

Araujo, Z., Otten, S., \& Brisci, S. (2017). Mathematics Teachers' Motivations for, Conceptions of, and Experiences with Flipped Instruction. Teaching and Teacher Education.

Ary, D., Jacobs, L., Sorensen, C., \& Razavieh, A. (2010). Introduction to Research in Education.

Awidi, I., \& Paynter, M. (2018). The Impact of a Flipped Classroom Approach on Student Learning Experience. Accepted Manuscript: Computers \& Education.

Bergmann, J., \& Sams, A. (2012). Flip Your Classroom.

Boyadzhieva, E. (2016). Learner-centered Teaching and Learner Autonomy. Social and Behavioral Science, $35-40$.

Chen, Y., Wang, Y., Kinshuk, \& Chen, N. S. (2014). Is FLIP Enough? or Should We Use the FLIPPED Model Instead? Computers \& Education.

Chi, M., \& Wylie, R. (2014). The ICAP Framework: Linking Cognitive Engagement to Active Learning Outcomes. Educational Psychologist, 219-243.

Dehghanzadeh, S., \& Jafaraghaie, F. (2018). Comparing the Effects of Traditional Lecturer and Flipped Classroom on Nursing Students' Critical Thinking Disposition: A Quasi-experimental Study. Nurse Education Today.

Duong, T. M., \& Seepho, S. (2014). Promoting Learner Autonomy: a Qualitative Study on EFL Teachers' Perceptions and Their Teaching Practices. In Proceedings of the International Conference.

Erturk, N. O. (2016). Language Learner Autonomy: Is it Really Possible? Social and Behavioral Sciences, 650-654.

Evseeva, A., \& Solozhenko, A. (2015). Use of Flipped Classroom Technology in Language Learning. Social and Behaviour Sciences.

Fauzan, A., \& Ngabut, M. (2018). EFL Students' Perception on Flipped Learning in Writing Class. Journal on English as a Foreign Language, 115-129.

Giesbers, B., Rienties, B., Tempelaar, D., \& Gijselaers, W. (2013). Investigating the Relations between Motivation, Tool Use, Participation, and Performance in an E-Learning Course Using WebVideoconferencing. Computers in Human Behavior.

Gilboy, M. B., Heinerichs, S., \& Pazzaglia, G. (2014). Enhancing Students Engagement Using the Flipped Classroom. Journal of Nutrition Education and Behavior, 1-6.

Haddad, R. H. (2016). Developing Learner Autonomy in Vocabulary Learning in classroom: How and Why can it be Fostered?. Procedia: Social and Behavioral Sciences., 784-791.

Hao, Y. (2016). Exploring Undergraduates' Perspectives and Flipped Learning Readiness in Their Flipped Classrooms. Computers in Human Behavior, 82-92. 
Hsieh, J. S., Huang, Y., \& Wu, W. F. (2017). Technology Acceptance of LINE in Flipped EFL Oral Training. Computers in Human Behaviour.

Hsieh, J. S., Wu, W. F., \& Marek, M. W. (2017). Using the Flipped Classroom to Enhance Flipped Learning. Computer Assisted Language Learning, 1-20.

Khalaf, B. K., \& Zin, Z. B. (2018). Traditional and InquiryBased Learning Pedagogy: A Systematic Critical Review. International Journal of Instruction.

Kirschner, P. A., Sweller, J., \& Clark, R. E. (2006). Why Minimal Guidance During Instruction Does Not Work: An Analysis of the Failure of Constructivist, Discovery, Problem-Based, Experiential, and Inquiry-Based Teaching. Educational Psychologist, 75-86.

Kong, S. C., \& Song, Y. (2015). An Experience of Personalized Learning Hub Initiative Embedding BYOD for Reflective Engagement in Higher Education. Computers \& Education, 227-240.

Lazar, A. (2013). Learner Autonomy and Its Implementation for Language Teacher Training. Procedia: Social and Behavioral Sciences, 460-464.

Lin, Y. T. (2018). Impacts of a Flipped Classroom with a Smart Learning Diagnosis System on Students' Learning Performance, Perception, and Problem Solving Ability in a Software Engineering Course. Accepted Manuscript: Computers in Human Behavior.

Lodico, M., Spaulding., \& Voegtle, K. (2010). Methods in Educational Research.

Najeeb, S. S. (2013). Learner Autonomy in Language Learning. Procedia: Social and Behavioral Sciences, 1238-1242.

Ng, E. M. (2018). Integrating Self-Regulation Principles with Flipped Classroom Pedagogy for First Year University Students. Accepted Manuscript: Computers \& Education.

Nouri, J. (2016). The Flipped Classroom: for Active, Effective, and Increased Learning - Especially for Low Achievers. International Journal of Educational Technology in Higher Education, 1-10.

Quyen, T. T. (2017). Students' Perceptions of Flipped Model on Facebook for Educational Purposes. IOSR Journal of Research \& Method in Education, 07-14.

Roach, T. (2014). Student Perceptions toward Flipped Learning: New Methods to Increase Interaction and Active Learning in Economics. International Review of Economics Education, 74-84.

Roth, C., \& Suppasetseree, S. (2016). Flipped Classroom: Can It Enhance English Listening Comprehension For Pre-University Students In Cambodia? Proceedings of CLaSIC, 255-264.

Sohrabi, B., \& Iraj, H. (2016). Implementing Flipped Classroom Using Digital Media: A Comparison of Two Demographically Different Groups Perceptions. Computers in Human Behaviour, 514-524.

Sojayapan, C., \& Khlaisang, J. (2018). The Effect of a Flipped Classroom with Online Group Investigation on
Students' Team Learning Ability. Kasetsart Journal of Social Sciences.

Soliman, N. A. (2016). Teaching English for Academic Purposes via the Flipped Learning Approach. Social and Behavioral Sciences. , 122-129.

Souza, M. J., \& Rodrigues. (2015). Investigating the Effectiveness of the Flipped Classroom in an Introductory Programming Course. The New Educational Review.

Tran, T. Q., \& Duong, T. M. (2018). EFL Learners' Perceptions of Factors Influencing Learner Autonomy Development. Kasetsart Journal of Social Sciences.

Trucano, M. (2005). Knowledge Maps: ICT in Education.

Wang, F. H. (2017). An exploration of online behavior engagement and achievement in flipped classroom supported by learning management system. Accepted Manuscript: Computers \& Education.

Yagcioglu, O. (2018). New approaches on learner autonomy in language learning. Procedia: Social and Behavioral Sciences, 428-435.

Yildirim, O. (2012). A Study on a Group of Indian English as a Second Language Learners' Perceptions of Autonomous Learning. Turkish Online Journal of Qualitative Inquiry, 18-29.

Yilmaz, R. (2017). Exploring the Role of E-learning Readiness on Student Satisfaction and Motivation in Flipped Learning. Computers in Human Behaviour, 251-260. 


\section{Appendix1. Questionnaire of Perception of Flipped Learning Experience}

This survey is to understand your overall perception of flipped learning in the course. There is no right or wrong answer. Please circle the answer, which best reflects your overall thoughts about each statement. You can write your reason for Bahasa Indonesia. Your answers are anonymous and confidential. Thank you in advance for your time.

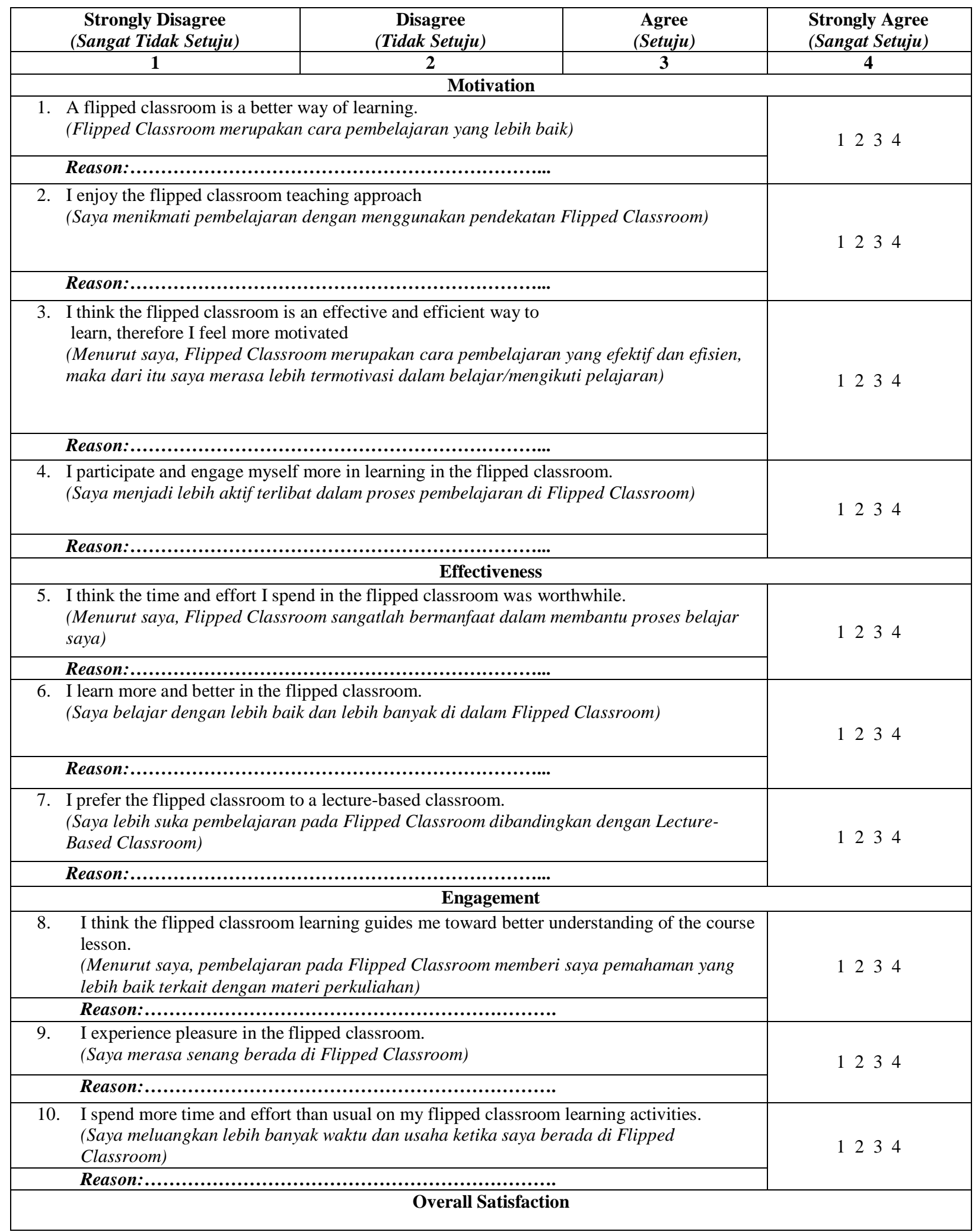


11. Generally, I am happy and satisfied with this flipped learning experience.

(Secara kesuluruhan, saya merasa senang dan puas dengan pengalaman saya di Flipped Classroom)

\section{Appendix 2.Questionnaire of Technology Acceptance Model}

This survey is to understand your overall learning perception of the use of E-learning in the course. There is no right or wrong answer. Please circle the answer, which best reflects your overall thoughts about each statement. You can write your reason for Bahasa Indonesia. Your answers are anonymous and confidential. Thank you in advance for your time.

\begin{tabular}{|c|c|c|c|}
\hline $\begin{array}{c}\text { Strongly Disagree } \\
\text { (Sangat Tidak Setuju) }\end{array}$ & $\begin{array}{c}\text { Disagree } \\
\text { (Tidak Setuju) }\end{array}$ & $\begin{array}{c}\text { Agree } \\
\text { (Setuju) }\end{array}$ & $\begin{array}{l}\text { Strongly Agree } \\
\text { (Sangat Setuju) }\end{array}$ \\
\hline 1 & 2 & 3 & 4 \\
\hline \multicolumn{4}{|c|}{ Perceived Ease of Use } \\
\hline $\begin{array}{l}\text { 1. Using E-learning doe } \\
\text { (Penggunaan E-learn }\end{array}$ & $\begin{array}{l}\text { too much time } \\
\text { merlukan waktu }\end{array}$ & & \multirow[t]{2}{*}{1234} \\
\hline \multicolumn{3}{|c|}{ 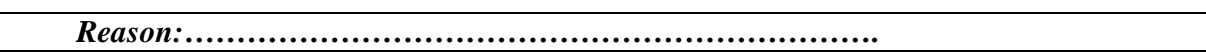 } & \\
\hline $\begin{array}{l}\text { 2. Learning to use E-lea } \\
\text { (Menggunakan E-lea }\end{array}$ & $\begin{array}{l}\text { class activities is } \\
\text { roses pembelajar }\end{array}$ & $g$ mudah) & \multirow[t]{2}{*}{1234} \\
\hline \multicolumn{3}{|c|}{ 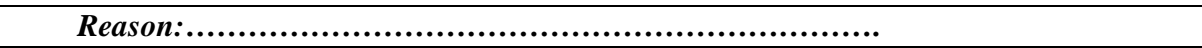 } & \\
\hline \multicolumn{4}{|c|}{$\begin{array}{ll}\text { Perceived Usefulness } \\
\end{array}$} \\
\hline $\begin{array}{l}\text { 3. Learning through E-1 } \\
\text { (Pembelajaran meng }\end{array}$ & $\begin{array}{l}\text { ides a beneficial } \\
\text { earning memberi }\end{array}$ & $\begin{array}{l}\text { ass. } \\
\text { idap pembelajaran) }\end{array}$ & \multirow[t]{2}{*}{1234} \\
\hline \multicolumn{3}{|c|}{ 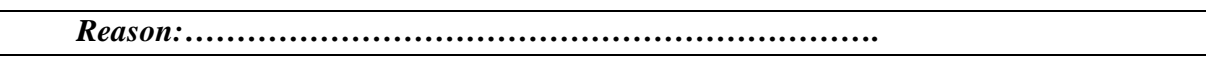 } & \\
\hline $\begin{array}{l}\text { 4. Learning through E-1 } \\
\text { (Pembelajaran meng } \\
\text { terhadap materi yang }\end{array}$ & $\begin{array}{l}\text { nces my desire or } \\
\text { earning dapat me } \\
\text { jari) }\end{array}$ & gin tahu saya & \multirow[t]{2}{*}{1234} \\
\hline \multicolumn{3}{|c|}{ Reason: } & \\
\hline $\begin{array}{ll}\text { 5. } & \text { Learning through E-1 } \\
\text { mine/peers } \\
\text { (Pembelajaran meng } \\
\text { ketika mengerjakan t }\end{array}$ & $\begin{array}{l}\text { igthened my criti } \\
\text { earning dapat me } \\
\text { i maupun kelomp }\end{array}$ & $\begin{array}{l}\text { consider the work of } \\
\text { rfikir kritis saya }\end{array}$ & \multirow[t]{2}{*}{1234} \\
\hline \multicolumn{3}{|c|}{ Reason: } & \\
\hline \multicolumn{4}{|c|}{ Attitude about Use } \\
\hline \multicolumn{3}{|c|}{$\begin{array}{l}\text { 6. I like using E-learning in downloading the materials and submitting my works. } \\
\text { (Saya suka menggunakan E-learning saat mengunduh materi dan mengumpulkan tugas) }\end{array}$} & \multirow[t]{2}{*}{1234} \\
\hline \multicolumn{3}{|c|}{ 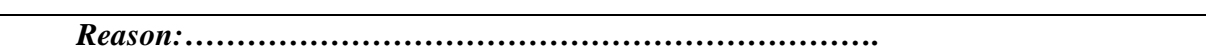 } & \\
\hline \multirow{2}{*}{$\begin{array}{l}\text { I have a positive attit } \\
\text { (Saya memiliki penda } \\
\text { Reason:................. }\end{array}$} & $\begin{array}{l}\text { ing E-learning in } \\
\text { entang penggunac }\end{array}$ & elas) & \multirow[t]{2}{*}{1234} \\
\hline & ...................... & & \\
\hline \multirow[t]{2}{*}{$\begin{array}{l}\text { I feel that using E-lea } \\
\text { (Menurut saya, peng } \\
\text { yang bagus) }\end{array}$} & $\begin{array}{l}\text { language learning } \\
\text { arning pada pemb }\end{array}$ & adalah gagasan & \multirow[t]{2}{*}{1234} \\
\hline & ....................... & & \\
\hline \multirow[t]{2}{*}{ I look forward to use } & $\begin{array}{l}\text { n this class. } \\
\text { ggunakan E-learn }\end{array}$ & & \multirow[b]{2}{*}{1234} \\
\hline & (n.................. & & \\
\hline
\end{tabular}

